\title{
Implementation of Value Engineering in Heat Treatment Process to Cooling Media Steel ST 41 at PT. XY
}

\author{
Sumiati*, Purwati, and Isna Nugraha \\ Industrial Engineering, Faculty of Engineering, Universitas of Pembangunan Nasional "Veteran” Jawa Timur, Indonesia
}

\begin{abstract}
Value engineering analyzes the value and function for optimal results and the condition of the steel material remains consistent according to its quality function. ST 41 steel is a steel classified as low carbon steel with an alloy composition of $0.37-0.43 \% \mathrm{C}, 0.5-0.35 \% \mathrm{Si}, 0.60-0.90 \% \mathrm{Mn}$. Heat treatment in this study uses temperatures up to $723^{\circ} \mathrm{C}$ with temperature holding for one hour, while the proposed alternative cooling media used are salt water, coconut oil, and oil using the holding time of each cooling medium, namely 5 minutes, 10 minutes to 15 minutes. Cooling using 3 media simultaneously is very ineffective and very expensive. The right solution to eliminate unnecessary costs, this research proposes salt water media as a good medium for performance and relatively low cost compared to other media tested. The analysis that occurs from the calculation of the value engineering cost is IDR 45,500,000.00 the heating process in 1 month produces 5000 specimens per day, which can save costs of IDR 15,750,000.00. Thus, the brine medium is able to provide criteria for the speed of the cooling process properly and provide good quality results for a continuous process.
\end{abstract}

Keyword: Value Engineering, Heat Treatment, Cooling Medium

\section{Introduction}

In general, value engineering (VE) is a functional approach to existing resources. This process is carried out to keep costs to a minimum while maintaining the desired quality. [1] The development of steel ST 41 products in Indonesia has grown quite rapidly so that many industrial companies focus more on this one material as the high value of their products. Steel ST 41 has different characteristics from other steel products, generally it has low carbon properties and functions as a manufacturing material such as gears, couplers and shafts and others. Other previous research according to El-Nashar \& Elyamany [2] states that value engineering (VE) is a measurable and directed approach to the functions of systems, equipment, facilities, services and supplies for the purpose of achieving their essential functions. The purpose of value engineering in the steel ST 41 heat treatment process at Company XY is to find the best solution for costs with the ability of a method to control the total cost of its function. Company PT. XY tries to find a solution related to the problems that occur in the case of the increasing cost of the heat treatment and quenching process by providing an initial alternative to the proposed alternative, for the cooling medium carried out on steel ST 41 with sampling 5 or 8 trials per cooling medium material.

The sampling experiment conducted is relatively small, to find out how much the heating and cooling process costs on steel ST 41. The value in the cooling medium is used to present strategies that can be applied to solve problems related to minimizing cooling process costs while maintaining the quality of products steel ST 41 to its function [3]. This research is a value engineering method on steel ST 41 research, this is a reference to reduce unnecessary costs when cooling from heat treatment results by comparing initial alternatives and proposals based on price variants [4]. The reason for using this research method is the ability of value engineering to control unnecessary costs and keep costs to a minimum while maintaining quality as needed, in a structured manner providing good functional value.

\section{Literature Review}

According to Tao \& Yu [5], value engineering is able to bring value engineering experts in processes and products so as to produce an integrated life cycle. In contrast to research from Heralova [6] stated that value engineering can be used to complete solutions related to highway project development that really need to save costs and improve project performance significantly. In this case, the research takes a value engineering approach by looking at functions based on pairwise matrix comparisons to find cost-saving solutions based on value with function compared to criteria and

\footnotetext{
* Corresponding author : sumiati.ti@upnjatim.ac.id
} 
alternatives after heat treatment occurs on steel ST 41 . The value engineering formula is as follows [7] :

$$
V E=\frac{P}{C} \text {. }
$$

$$
\mathrm{P}=\text { Performance, } \mathrm{C}=\text { Cost }
$$

Provided that the VE index value is $>(1-1.5)$. In solving this case, research requires further information by collecting cooling media data to find the most important function of cost savings. According to Taherdoost [8], the hierarchical tree below can be used as a reference to determine the function of a case to be solved. This research is limited to calculating the characteristics through the tensile test. Tensile test is a test of a material by applying a tensile load to the material with the following formulation:

$$
\sigma=\frac{\mathrm{F}}{\mathrm{A} 0} \text {. }
$$

$\mathrm{F}=$ Tensile load

$\mathrm{A}_{0}=$ Initial cross-sectional area

The material used in this study is ST 41 steel which has different properties where this steel has a low carbon material. The characteristics of steel ST 41 along with the heat treatment process are as follows:

a. Steel

According to Isworo \& Rahman [9] stated that steel ST 41 is one of the low carbon steel classes because the content of steel ST 41 contains carbon (C) of $0.08 \%-0.2 \%$. Carbon steel has a carbon content of ferrous about $0.2 \%$ to $2.14 \%$, where the carbon content serves as a reinforcing element in the steel structure. Steel ST 41 basically consists of a mixture of ferrite and ferlite equal to or equal to $\mathrm{S} 40 \mathrm{C}$ steel (JIS, G4051), consisting of a mixture of 0.37 $0.43 \% \mathrm{C}, 0.5-0.35 \% \mathrm{Si}, 0.60-0.90 \% \mathrm{Mn}$.

b. Heat Treatment

Basically, the ST 41 material in the research carried out a process of heating, holding and cooling the alloy or metal where the metal was initially in a solid state then went through a process to get metal that was regulated to obtain certain properties as needed. Heat treatment generally consists of several stages, starting with heating to a certain temperature, then followed by holding the temperature so that cooling is obtained a certain speed.

c. Holding Time

This process is a process that requires holding time where this process holds temperatures above the critical temperature at the austenization temperature with the aim of getting the maximum hardness of a material or material to obtain a homogeneous austenite structure from the solubility of carbide or until diffusion of the alloying elements occurs with carbon. For steel type and olding time as follows: Low carbon steel $5-15$ minutes, medium alloy steel Low 15 - 25 minutes, alloy tool steel high 10 - 30 minutes, alloy tool steel hot $10-60$ minutes, work tool steel $15-30$ minutes.

d. Quenching Process

Quenching process is a fast cooling process after going through heat treatment. The initial alternative for cooling media in this study was air and oil aquades because they have a lower viscosity so that they can be used as cooling media to accelerate the cooling rate critically to get higher hardness. However, the proposal in this research is that the cooling media in this quenching process are salt water, oil SAE $20 \mathrm{~W}-50$ and furnace.

Various alternative cooling media used for the quenching process:

1. Cooling Water Media $\left(\mathrm{V}=998 \mathrm{~kg} / \mathrm{m}^{3}\right)$.

Water is a chemical compound with the chemical formulation $\mathrm{H}_{2} \mathrm{O}$. This means that a water molecule is composed of two hydrogen atoms bonded to one oxygen atom. Water is colorless, tasteless, odorless.

2. Salt Water cooling medium $\left(\mathrm{V}=1025 \mathrm{~kg} / \mathrm{m}^{3}\right)$. Salt water is used as a cooling element because it has the property of cooling regularly and quickly.

3. Oil cooling medium ( $\mathrm{V}=981 \mathrm{~kg} / \mathrm{m} 3$ )

The oil used as the cooling fluid in the heat treatment is obtained to provide a coating of the workpiece being processed. In addition to special oils used fuel oil.

4. Coconut Oil

The oil used as a cooling fluid in heat treatment is one that can provide a carbon layer on the skin (surface) of the workpiece being processed.

5. Air

Air cooling is carried out for heat treatment which requires slow cooling. The air that is circulated into the cooling chamber is made at a low speed. Air as a coolant will provide an opportunity for the metal to form crystals and possibly bind other elements from the air.

\section{Research Methods}

In this research, it is necessary to take the following steps:

1. Data on the ST 41 steel heat treatment process that has been carried out

2. Tensile strength test

3. The value of the pairwise comparison matrix

4. The final cost value data is based on experiments on sampling specimens (40 pieces) of ST 41 steel.

5. Identifying function values based on criteria and alternative media in the form of independent variables consisting of price, cooling process speed and quality and the dependent variable consisting of initial cooling media $(500 \mathrm{ml}$ aquades, air, $500 \mathrm{ml}$ oil) and proposals (500 $\mathrm{ml}$ salt water) grams, coconut water and stove).

6. The maximu size of the ST 41 steel specimen used is $4,5 \mathrm{~mm} \times 22,28 \mathrm{~mm}$ as a determination of the value of the score in the calculation of the paired matrix, the thing that needs to be followed is the subjective value must be in accordance with the important score standard that is fundamental to a variable [10]. 
Table 1. The Fundamental Important Score of a Variable

\begin{tabular}{|c|l|}
\hline Scale & Skala Explanation of the Definition of Scale \\
\hline 1 & $\begin{array}{l}\text { Both are important and have contributed to the } \\
\text { goal }\end{array}$ \\
\hline 2 & Medium and important priority \\
\hline 3 & Have a moderate interest among other interests \\
\hline 4 & Moderate to very important is preferred \\
\hline 5 & $\begin{array}{l}\text { Important or strong importance / very important } \\
\text { priority }\end{array}$ \\
\hline 6 & Very to very important is preferred to be selected \\
\hline 7 & $\begin{array}{l}\text { Very strong interest in the activity is very } \\
\text { preferable to choose }\end{array}$ \\
\hline 8 & $\begin{array}{l}\text { So strong that it is very important to take } \\
\text { precedence }\end{array}$ \\
\hline 9 & $\begin{array}{l}\text { Very important evidence for one activity from } \\
\text { another activity }\end{array}$ \\
\hline
\end{tabular}

The value above is very necessary when calculating pairwise comparison matrices, so that the final value will be valid.

\section{Results And Discussion}

The results of the tensile sampling test are in the form of steel ST 41 specimens by a team from PT. XY located in Jakarta The results of the tensile test are in the form of ST 41 steel specimens by a team from PT. XY located in Jakarta is as shown in table 2. Description: the price of 1 specimen is IDR. $1,500.00 /$ piece, the price currently on the market.

The next step is to select the media that has been used above to eliminate unnecessary costs by determining the function of each cooling medium selection.

Table 2. Data Results of Heat Treatment and Quenching Process

\begin{tabular}{|c|c|c|c|c|c|c|c|c|c|}
\hline No & $\begin{array}{l}\text { Variatio } \\
\text { n of } \\
\text { Holding } \\
\text { Time }\end{array}$ & $\begin{array}{c}\text { Temperature } \\
\left(\mathrm{C}^{0}\right)\end{array}$ & $\begin{array}{l}\text { Thick } \\
(\mathrm{T}) \\
(\mathrm{mm})\end{array}$ & $\begin{array}{l}\text { Wide (T) } \\
(\mathrm{mm})\end{array}$ & $\begin{array}{l}\text { Cross-sectional } \\
\text { Area } A 0=\mathrm{TxL} \\
\quad(\mathrm{mm} 2)\end{array}$ & $\begin{array}{l}\text { Tensile } \\
\text { Load Max } \\
\text { (P) kN }\end{array}$ & $\begin{array}{c}\text { Tensile } \\
\text { Load Max } \\
(\mathrm{P})(\mathrm{N})\end{array}$ & $\begin{array}{l}\text { Tensile } \\
\text { Strength } \sigma \\
=\text { P/A0 }\end{array}$ & $\begin{array}{c}\text { Steel } \\
\text { Price } \\
\text { ST 41 } \\
\text { perbuah }\end{array}$ \\
\hline 1 & \multirow{5}{*}{$\begin{array}{c}\text { Raw } \\
\text { Material }\end{array}$} & \multirow{5}{*}{$\begin{array}{l}\text { No Heat } \\
\text { Treatment }\end{array}$} & 4,45 & 21,21 & 94,38 & 44,45 & 44450 & 470,95 & 1.500 \\
\hline 2 & & & 4,35 & 20,23 & 88,00 & 44,21 & 44210 & 502,38 & 1.500 \\
\hline 3 & & & 4,43 & 21,25 & 94,14 & 44,35 & 44350 & 471,12 & 1.500 \\
\hline 4 & & & 4,38 & 22,25 & 97,46 & 44,26 & 44260 & 454,16 & 1.500 \\
\hline 5 & & & 4,42 & 22,28 & 98,48 & 44,25 & 44250 & 449,34 & 1.500 \\
\hline & Average & & 4,41 & 21,44 & 94,49 & 44,30 & 44304 & 469,59 & 1.500 \\
\hline 1 & & \multirow{5}{*}{$650^{\circ}$} & 5,38 & 23,75 & 127,78 & 45,45 & 45450 & 355,70 & 1.500 \\
\hline 2 & & & 5,04 & 23,85 & 120,20 & 45,25 & 45250 & 376,44 & 1.500 \\
\hline 3 & $\begin{array}{c}5 \\
\text { minutes }\end{array}$ & & 5,08 & 23,63 & 120,04 & 45,56 & 45560 & 379,54 & 1.500 \\
\hline 4 & & & 5,21 & 23,75 & 123,74 & 45,58 & 45580 & 368,36 & 1.500 \\
\hline 5 & & & 5,16 & 23,87 & 123,17 & 45,25 & 45250 & 367,38 & 1.500 \\
\hline & Average & & 5,17 & 23,77 & 122,99 & 45,42 & 45418 & 369,49 & 1.500 \\
\hline 1 & & \multirow{5}{*}{$700^{\circ}$} & 5,45 & 24,95 & 135,98 & 47,43 & 47430 & 348,81 & 1.500 \\
\hline 2 & & & 5,08 & 24,91 & 126,54 & 47,41 & 47410 & 374,66 & 1.500 \\
\hline 3 & $\begin{array}{c}10 \\
\text { minutes }\end{array}$ & & 5,15 & 24,75 & 127,46 & 47,72 & 47720 & 374,38 & 1.500 \\
\hline 4 & & & 5,25 & 24,84 & 130,41 & 47,58 & 47580 & 364,85 & 1.500 \\
\hline 5 & & & 5,22 & 24,75 & 129,20 & 47,46 & 47460 & 367,35 & 1.500 \\
\hline & Average & & 5,23 & 24,84 & 129,92 & 47,52 & 47520 & 366,01 & 1.500 \\
\hline 1 & & \multirow{6}{*}{$723^{0}$} & 5,55 & 25,09 & 139,25 & 48,45 & 48450 & 347,94 & 1.500 \\
\hline 2 & & & 5,12 & 25,03 & 128,15 & 48,47 & 48470 & 378,22 & 1.500 \\
\hline 3 & $\begin{array}{c}15 \\
\text { minutes }\end{array}$ & & 5,25 & 25,04 & 131,46 & 48,79 & 48790 & 371,14 & 1.500 \\
\hline 4 & & & 5,31 & 25,11 & 133,33 & 48,67 & 48670 & 365,02 & 1.500 \\
\hline 5 & & & 5,25 & 25,12 & 131,88 & 48,88 & 48880 & 370,64 & 1.500 \\
\hline & Average & & 5,30 & 25,08 & 132,82 & 48,65 & 48652 & 366,59 & 1.500 \\
\hline
\end{tabular}




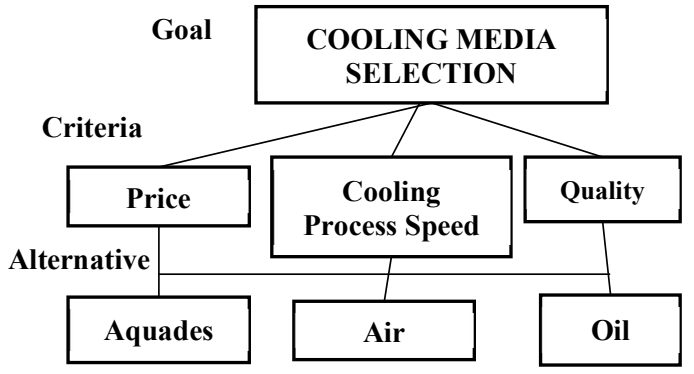

Fig. 1. Initial Cooling Media Selection

Figure 1 shows the function of selecting the initial cooling medium for steel ST 41, the next step is to calculate the pairwise comparison matrix of the initial medium.

Table 3. Calculations Based on Functions and Benefits

\begin{tabular}{|l|r|r|r|r|r|}
\hline $\begin{array}{c}\text { Cooling } \\
\text { Media }\end{array}$ & Price & $\begin{array}{c}\text { Cooli } \\
\text { ng } \\
\text { Proce } \\
\text { ss } \\
\text { Speed }\end{array}$ & Quality & Criteria & Alternative \\
\hline $\begin{array}{l}\text { Aquade } \\
\text { s }\end{array}$ & 0,27 & 0,69 & 0,48 & 0,09 & 0,51 \\
\hline Air & 0,64 & 0,10 & 0,37 & 0,25 & 0,33 \\
\hline Oil & 0,09 & 0,21 & 0,15 & 0,66 & 0,16 \\
\hline Total & 1,00 & 1,00 & 1,00 & 1,00 & 1,00 \\
\hline
\end{tabular}

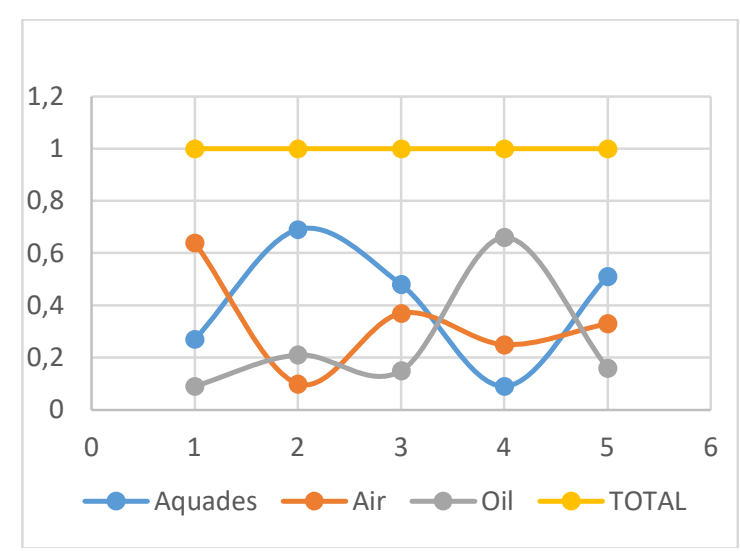

Fig. 2. Initial Cooling Media Function Value

Table 3 and Figure 2 are the results of calculations using pairwise comparison matrices and graphic images show that salt media is the best cooling medium in dissolving the hardness test after the heat treatment process[11]. The highest score was obtained by Aquades media. The cost of Value Engineering media Aquades $500 \mathrm{ml}$ for 5 trials can be obtained as follows:
Table 4. Calculation of Value Engineering on $500 \mathrm{ml}$ Aquades Media for 5 Experiments

\begin{tabular}{|c|c|c|c|c|c|c|}
\hline No & $\begin{array}{l}\text { Number of } \\
\text { Spicemen } \\
\text { for } \\
\text { Experiment }\end{array}$ & $\begin{array}{c}\text { Aqua } \\
\text { des } \\
\text { Price } \\
\text { (IDR) } \\
\text { (A) }\end{array}$ & $\begin{array}{l}\text { Specime } \\
\text { n Price } \\
\text { (IDR) } \\
\text { (B) }\end{array}$ & $\begin{array}{c}\text { Functi } \\
\text { on } \\
\text { Cost } \\
\text { (IDR) } \\
\text { (A)+(B } \\
=(\mathrm{C})\end{array}$ & $\begin{array}{c}\text { Cost } \\
\text { Value } \\
\text { (IDR) } \\
(0,51) \\
* \\
\text { (C) } \\
\text { (D) }\end{array}$ & $\begin{array}{l}\mathrm{VE} \\
= \\
(\mathrm{C} / \\
\mathrm{D})\end{array}$ \\
\hline 1 & 8 & \multirow{6}{*}{$\begin{array}{c}10,00 \\
0\end{array}$} & 1,500 & \multirow{6}{*}{17,500} & \multirow{6}{*}{8925} & \multirow{6}{*}{$\begin{array}{c}1,9 \\
6\end{array}$} \\
\hline 2 & 8 & & 1,500 & & & \\
\hline 3 & 8 & & 1,500 & & & \\
\hline 4 & 8 & & 1,500 & & & \\
\hline 5 & 8 & & 1,500 & & & \\
\hline \multicolumn{2}{|c|}{ Total $=40$} & & 7,500 & & & \\
\hline
\end{tabular}

Table 4 of the VE calculation is known to still contain a value of 1.96 , meaning that the costs incurred are still relatively high for PT.XY. Therefore, it is necessary to recommend a suitable cooling medium to be proposed as an alternative to minimize the cost of the heat treatment process. Aquades content as much as $500 \mathrm{ml}$ of water along with the calculation between the price per 500 grams of fine salt with market prices ranging from IDR. 10,000.00 with $500 \mathrm{ml}$ Aquades, this experiment is able to accommodate 5 to 8 ST 41 steel specimens. The performance of Aquades is in terms of price, cooling process speed and quality of 0.51 and the total cost of the experiment is IDR. 17,500.00. It can be interpreted that the cost is quite high if PT. XY performs the heat treatment process in a large capacity.

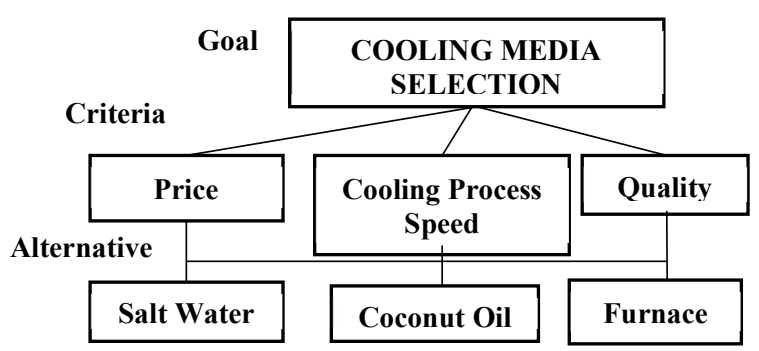

Fig. 3. Selection of Recommended Cooling Media

Figure 3 shows the functions and benefits of choosing the recommended cooling medium for steel ST 41, then calculates the pairwise comparison matrix from the initial medium.

Table 5. Calculations Based on Functions and Benefits

\begin{tabular}{|l|r|r|r|r|r|}
\hline $\begin{array}{c}\text { Cooling } \\
\text { Media }\end{array}$ & Price & $\begin{array}{c}\text { Cooling } \\
\text { Process } \\
\text { Speed }\end{array}$ & Quality & Criteria & Alternative \\
\hline $\begin{array}{l}\text { Salt } \\
\text { Water }\end{array}$ & 0,69 & 0,65 & 0,65 & 0,09 & 0,65 \\
\hline $\begin{array}{l}\text { Coconut } \\
\text { Oil }\end{array}$ & 0,10 & 0,10 & 0,10 & 0,25 & 0,10 \\
\hline Furnace & 0,21 & 0,25 & 0,25 & 0,66 & 0,25 \\
\hline Total & 1,00 & 1,00 & 1,00 & 1,00 & 1,00 \\
\hline
\end{tabular}




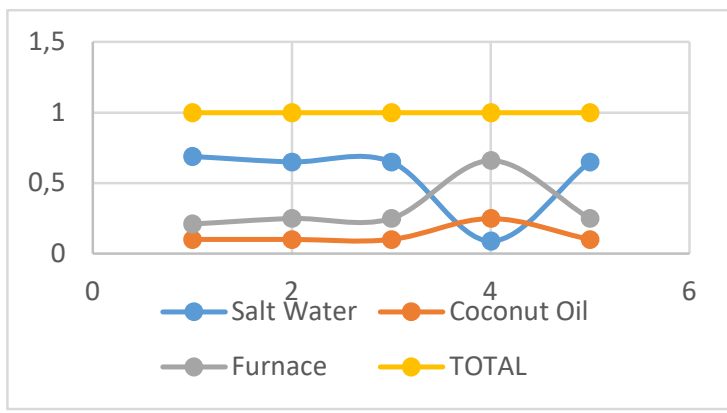

Fig. 4. Functions and Benefits of the Recommended Cooling Media
Table 5 and Figure 4 show the results of the calculation of the pairwise comparison matrix and the graph of the function of the Salt Water cooling medium. This material is good for the quenching process. Salt water is obtained from mixing $\left(\mathrm{H}_{2} \mathrm{O}+\mathrm{NaCL}\right)$ [12] in a ratio of $500 \mathrm{ml}$ of water: 2 tablespoons. The price per 500 grams of fine salt according to the market price ranges from IDR. 5,500.00 using $500 \mathrm{ml}$ of salt water with a capacity of 5 to 8 steel ST 41 specimens for 5 trials. The calculation of value engineering is as follows:

Table 6. Value Engineering Salt Water Media $500 \mathrm{ml}$ for 5 trials

\begin{tabular}{|c|c|c|c|c|c|c|c|}
\hline No & $\begin{array}{l}\text { Numb of } \\
\text { Spicemen for } \\
\text { Experimen }\end{array}$ & $\begin{array}{l}\text { Salt water } \\
\text { used (ml) }\end{array}$ & $\begin{array}{l}\text { Salt Water Price } \\
\text { (IDR) } \\
\text { (E) }\end{array}$ & $\begin{array}{c}\text { Specimen } \\
\text { Price (IDR) } \\
\text { (F) }\end{array}$ & $\begin{array}{c}\text { Function Cost } \\
\text { (IDR) } \\
(\mathrm{E})+(\mathrm{F})=(\mathrm{G})\end{array}$ & $\begin{array}{l}\text { Cost Value } \\
\text { (IDR) } \\
(0,65)^{*} \\
(\mathrm{G})=(\mathrm{H})\end{array}$ & $\begin{array}{l}\mathrm{VE}= \\
(\mathrm{H} / \mathrm{F})\end{array}$ \\
\hline 1 & 8 & \multirow{6}{*}{500} & 5.500 & 1.500 & \multirow{6}{*}{13,000} & \multirow{6}{*}{8450} & \multirow{6}{*}{1,54} \\
\hline 2 & 8 & & 5.500 & 1.500 & & & \\
\hline 3 & 8 & & 5.500 & 1.500 & & & \\
\hline 4 & 8 & & 5.500 & 1.500 & & & \\
\hline 5 & 8 & & 5.500 & 1.500 & & & \\
\hline & Total $=40$ & & 5,500 & 7500 & & & \\
\hline
\end{tabular}

Table 6 shows that the value of VE costs is low, namely 1.54 which means that it is still below $>1.5$, the condition is feasible to be used by PT. XY after doing the test using salt water media that is IDR. 13,000.00 with a duration of 5 minutes, 10 minutes and 15 minutes, the advantage of this media is that it has a fairly high function value of 0.65 .

Analysis of the calculation using Value Engineering shows the costs that need to be eliminated when carrying out the quenching process using the recommended cooling medium [13], namely salt water, which is able to absorb costs of IDR. $13,000.00$ in 5 trials of 40 specimens, meaning that PT. XY can use this recommendation as a reference for financing the quenching process where the company's ability to produce once for the resulting output reaches 5000 specimens per day. In a month, that is 28 days for 5 times of work. Total operating costs of industrial companies at PT. XY for 1 month heat treatment process requires a cost of IDR. 45,500,000.00 /month. Meanwhile, the cost of using Aquades media at the beginning was IDR. $61,250,000.00$. From the results of the calculation of the heat treatment process for 1 month, it can be seen that there is a significant difference for large scale companies, with a small sampling trial showing the ability to eliminate unnecessary costs of IDR. 15.75 million. The advantage of the function of salt water is that it is superior to aquadest [14] if it is seen that the average criteria for the cooling process speed and quality are 0.65 compared to salt water, which is 0.51 in average, only 0.14 points. The value of 0.14 has a fairly strong influence in terms of the quality of the hardness of the steel ST 41 itself. Comparison of the two-cooling media proposed by Aquades, which is superior in terms of quality and speed of the cooling process [15], but to achieve good final quality and hardness, it is still relatively expensive to offer. The price of specimens will relatively increase when processed for various needs such as nuts, gears and others.

\section{Conclusion}

Brine media has a fairly high viscosity, namely ( $\mathrm{V}=$ $1025 \mathrm{~kg} / \mathrm{m}^{3}$ ), besides the ingredients are easy to get but it is easy to mix. This salt water has a regular and relatively fast cold nature, on the other hand is when water is mixed with salt the color of the water will turn not clear and classified as concentrated [16]. The result of this mixing becomes harder on the surface of the workpiece after the heat treatment process. The advantage of the value engineering side is that functionally it has its own advantages compared to other cooling media. The criteria can be achieved when in terms of price [17], speed in the cooling process and quality, there is a significant increase, so that it can help industry players as a material for consideration as a basic material for cooling media for mass production processes on heat treatment of steel ST 41 .

\section{References}

[1] Yu, M., Robati, M., Oldfield, P., Wiedmann, T., Crawford, R., Nezhad, A. A., \& Carmichael, D. "The impact of value engineering on embodied greenhouse gas emissions in the built environment: A hybrid life cycle assessment", Building and Environment, 168, 106452, (2020).

[2] El-Nashar, W. Y., \& Elyamany, A. H. "Value engineering for canal tail irrigation water problem", Ain Shams Engineering Journal, 9(4), 1989-1997, (2018). 
[3] Miladi Rad, K., \& Aminoroayaie Yamini, O. "The Methodology of Using Value Engineering in Construction Projects Management", Civil Engineering Journal, 2(6), 262, (2016).

[4] Ilayaraja, K., \& Zafar Eqyaabal, M. "Value Engineering in Construction", Indian Journal of Science and Technology, 8(32), 3-10, (2015).

[5] Tao, J., \& Yu, S. "Product Life Cycle Design for Sustainable Value Creation: Methods of Sustainable Product Development in the Context of High Value Engineering", Procedia CIRP, 69(May), 25-30, (2018).

[6] Heralova, R. S. "Possibility of Using Value Engineering in Highway Projects", Procedia Engineering, 164(June), 362-367, (2016).

[7] Bodman, G. "Value Engineering", South African Mechanical Engineer, 33(7), 183-188, (1983).

[8] Taherdoost, H. "Decision Making Using the Analytic Hierarchy Process (AHP); A Step by Step Approach", International Journel of Economics and Management Systems, 2(February), 244-246, (2017).

[9] Isworo \& Rahman. "Pengaruh Variasi Temperatur Pemanasan Dan Media Pendingin Terhadap Kekerasan Dan Struktur Mikro Baja St 41 Metode Hardening", SJME Kinematika, 5(1), 37-50, (2020).

[10] Zuraidi, S. N. F., Rahman, M. A. A., \& Akasah, Z. A. "A Study of using AHP Method to Evaluate the Criteria and Attribute of Defects in Heritage Building", E3S Web of Conferences, 65, 1-14, (2018).

[11] Alghamdi, A.O., Ayirala, S.C., Al-Otaibi, M., \& Al-Yousef, A. "Electro-kinetically tailored interfaces for chemical enhanced oil recovery in carbonates", Journal of Petroleum Science and Engineering, 207, art.no. 109053, (2021).

[12] Edachery, V., Swamybabu, V., Gurupatham, A., Paramasamy, M., \& Kailas, S.V. "The role of surface topography and normal load in the initiation of ratchetting-peak friction, seizure, scuffing, and elastic shakedown", Journal of Tribology, 144 (2), art.no. 021704, (2021).

[13] Al Dhaif, R., Ibrahim, A.F., \& Elkatatny, S. "Prediction of Surface Oil Rates for Volatile Oil and Gas Condensate Reservoirs Using Artificial Intelligence Techniques", Journal of Energy Resources Technology, Transactions of the ASME, 144 (3), art.no. 033001, (2021).

[14] Miaoyuan, L., Yuwan, L., Yi, L., Bei, C., \& Li, Z. "Research hotspots and application value of tissueengineered skin", Chinese Journal of Tissue Engineering Research, 26 (1), art.no.20954344(2022)01-00159-08, pp. 159-166, (2021).

[15] Lim, S., Kim, S.J., Park, Y., \& Kwon, N. "A deep learning-based time series model with missing value handling techniques to predict various types of liquid cargo traffic", Expert Systems with Applications, 184, art.no. 115532, (2021).

[16] Baniasadi, H., \& Rashidi, F. "A triple-porosity radial composite model for two-phase well test analysis of volatile oil in fractured-vuggy reservoirs", Scientia Iranica, 28 (3), pp. 13781399, (2021).

[17] E. Widodo, K. Takahashi, K. Morikawa, I. N. Pujawan, and B. Santosa, "Managing sales return in dual sales channel: its product substitution and return channel analysis," International Journal of Industrial and Systems Engineering, vol. 9, pp. 121-149, (2011). 